\title{
Pembelajaran Berbasis Masalah dalam Meningkatkan Kemampuan Pemecahan Masalah Matematika
}

\author{
${ }^{1}$ Erna Novianti, ${ }^{2}$ Putri Yuanita, ${ }^{3}$ Maimunah \\ 1,2,3 Department of Mathematics Education, FKIP, Riau Unversity, Indonesia \\ Email:1ernanovianti225@gmail.com,2putri.yuanita@lecturer.unri.ac.id, ${ }^{3}$ maimunah@lecturer.unri.ac.id
}

\begin{abstract}
This study aim is to improve the learning process and the student's mathematical problem solving skill by applying Problem Based Learning(PBL) model. This type of research is classroom action research with two cycles. This research was conducted in collaboration between researcher and teacher of mathematics. Subjects were students of class VII SMPN 9 Pekanbaru.Study was conducted in the odd semester of academic year 2019/2020. The research instrument consists of mathematical learning instruments and instruments to collect data. Mathematical learning instruments used in this study are syllabus, lesson plans , and activity sheets. Data collection instruments used in this study is observation sheets and mathematical problem solving tests. Data analysis technique in this study is analysis descriptive narrative of qualitative data and descriptive statistical analysis of quantitative data. The result of this study showed that the implementation of PBL improved the learning process and the student's mathematical problem solving skill. The student' saverage value in cycle I which is 70,27 had improved to 84,07 in cycle II. The improvement also found in the indicator average value in understanding the problem $(94,99)$, planning a solution $(69,71)$, implementing the pland $(82,77)$, and checking again $(54,85)$. This study concludes that the implementation of PBL improved the student's mathematical problem solving skill at class VII-2 SMPN 9 Pekanbaru
\end{abstract}

Keyword: Problem Based Learning,Mathematical Problem Solving Skill

\begin{abstract}
Abstrak: Penelitian ini bertujuan untuk meningkatkan Kemampuan Pemecahan Masalah Matematis (KPMM) peserta didik melalui penerapan model Problem Based Learning (PBL). Jenis penelitian ini adalah penelitian tindakan kelas dengan dua siklus. Penelitian ini merupakan penelitian tindakan kelas kolaboratif antara peneliti dengan guru matematika. Subjek penelitian ini adalah peserta didik kelas VII-2 SMPN 9 Pekanbaru. Penelitian ini dilaksanakan pada semester ganjil tahun pelajaran 2019/2020. Instrumen penelitian terdiri dari perangkat pembelajaran dan instrument pengumpul data. Perangkat pembelajaran yang digunakan dalam penelitian ini adalah silabus, Rencana Pelaksanaan Pembelajaran (RPP), dan Lembar Kerja Peserta Didik (LKPD). Instrumen pengumpul data yang digunakan dalam penelitian ini adalah lembar pengamatan dan tes KPMM. Teknik analisis data yang digunakan adalah teknik analisis deskriptif naratif untuk data kualitatif dan teknik analisis statistik deskriptif untuk data kuantitatif. Hasil penelitian menunjukkan bahwa penerapan PBL berhasil meningkatkan KPMM peserta didik. Rata-rata nilai KPMM peserta didik pada siklus I sebesar 70,27 meningkat menjadi 84,07 pada siklus II. Peningkatan rata-rata nilai KPMM peserta didik juga terjadi pada setiap indikator KPMM, yaitu memahami masalah $(94,99)$, merencanakan penyelesaian $(69,71)$, melaksanakan rencana $(82,77)$,dan mengecek kembali $(54,85)$. Berdasarkan hasil penelitian, maka dapat disimpulkan bahwa penerapan model ProblemBased Learning dapat meningkatkan KPMM peserta didik kelasVII-2 SMPN 9 Pekanbaru.
\end{abstract}

Kata Kunci: Problem Based Learning, Kemampuan Pemecahan Masalah Matematis

\section{PENDAHULUAN}

Matematika merupakan salah satu disiplin ilmu yang memiliki tujuan pembelajaran.Hal ini dapat dilihat dengan ditetapkannya matematika sebagai salah satu 
mata pelajaran wajib dalam setiap Ujian Akhir Nasional (UAN).Tujuan yang diharapkan dalam pembelajaran matematika oleh NCTM (dalam Widodo. S \& Kartika Sari, 2017) adalah: (1) Kemampuan pemecahan masalah; (2) Kemampuan berargumentasi; (3) Kemampuan berkomunikasi; (4) Kemampuan membuat koneksi; dan (5) Kemampuan representasi.

Menurut Hendriana dkk (2017) pada dasarnya kemampuan pemecahan masalah matematis merupakan suatu kemampuan matematis yang penting dan perlu dikuasai peserta didik yang belajar matematika. Kemampuan pemecahan masalah matematis sangat penting bagi peserta didik bukan saja untuk mempermudah peserta didik mempelajari pembelajaran matematika, namun dalam pembelajaran lain dan dalam kehidupan sehari-hari. Menurut Polya (dalam Mawaddah. S \& Hana Anisah, 2015) langkah-langkah pemecahan masalah matematis terdiri dari memahami masalah, merencanakan penyelesaian, melaksanakan rencana dan memeriksa kembali. Peserta didik dapat dikatakan mampu menyelesaikan atau memecahkan suatu masalah, apabila ia telah dapat melaksanakan empat tahapan pemecahan masalah yang telah dikemukakan Polya.

Hasil wawancara peneliti dengan guru matematika mengenai proses pembelajaran di kelas VII-2 SMPN 9 Pekanbaru, di peroleh informasi bahwa ketika proses pembelajaran berlangsung, peserta didik hanya menerima apa yang disampaikan oleh guru, tidak berusaha secara mandiri untuk mencari materi penunjang mengenai materi yang dipelajari. Selain itu, informasi yang peneliti peroleh dari guru adalah peserta didik kurang terbiasa mengerjakan soal pemecahan masalah. Menurut penjelasan guru, kondisi ini dikarenakan soal pemecahan masalah diberikan setelah soal-soal rutin, sehingga peserta didik tidak memiliki cukup waktu untuk mengerjakan soal pemecahan masalah.Sedangkan berdasarkan observasi peneliti, proses pembelajaran di kelas tidak mengaitkan dalam kehidupan sehari-hari. Sebagian besar dari mereka tidak mampu menghubungkan antara apa yang mereka pelajari dengan bagaimana pengetahuan tersebut akan dipergunakan dan dimanfaatkan. Seharusnya pelaksanaan kegiatan pembelajaran dilakukan berdasarkan Permendikbud nomor 22 tahun 2016 kurikulum 2013 berbasis aktivitas dengan karakteristik yaitu interaktif, inspiratif, menyenangkan, menantang, memotivasi peserta didik untuk berpartisipasi aktif, serta memberikan ruang yang cukup bagi prakarsa, kreativitas, dan kemandirian sesuai dengan bakat, minat dan perkembanagan fisik serta psikologis peserta didik.

Berdasarkan observasi tersebut, peneliti melakukan tes awal Kemampuan Pemecahan Masalah Matematis (KPMM) tetang materi yang telah dipelajari sebelumnya pada peserta didik kelas VII-2 SMPN 9 Pekanbaru, yaitu materi himpunan. Soal tes merujuk pada tahap-tahap dalam proses pemecahan masalah. Hasil pengukuran KPMM dari 40 peserta didik kelas VII-2 SMPN 9 Pekanbaru dapat dilihat pada Tabel 1 berikut.

Tabel 1. Persentase Jumlah Peserta Didik Kelas VII-2 SMPN 9 Pekanbaru yang Memenuhi Aspek KPMM

\begin{tabular}{|c|c|c|c|c|}
\hline No & Aspek KPPM yang Diukur & $\begin{array}{c}\text { Jumlah Peserta } \\
\text { Didik yang } \\
\text { Memenuhi Aspek }\end{array}$ & $\begin{array}{c}\text { Jumlah Peserta } \\
\text { Didik yang Tidak } \\
\text { Memenuhi Aspek }\end{array}$ & Persentase \\
\hline 1 & Memahami Masalah (MM) & 11 & 29 & $55 \%$ \\
\hline 2 & $\begin{array}{l}\text { Merencanakan Penyelesaian } \\
\text { (MP) }\end{array}$ & 9 & 31 & $45 \%$ \\
\hline 3 & Melaksanakan Rencana (MR) & 9 & 31 & $45 \%$ \\
\hline 4 & Memeriksa Kembali (MK) & 5 & 35 & $25 \%$ \\
\hline
\end{tabular}


Tabel 1, menunjukkan bahwa KPMM peserta didik belum baik. Pada aspek memahami masalah dari 40 peserta didik hanya 11 peserta didik yang menuliskan diketahui dan ditanya, beberapa peserta didik tidak melakukan tahapan tersebut, namun langsung mengerjakan soal. Pada aspek merencanakan penyelesaian, hanya 9 peserta didik dari 40 peserta didik yang dapat merencanakan strategi pemecahan masalah dimana strategi sudah tepat dan lengkap.Pada aspek melaksanakan rencana, yaitu melaksanakan rencanadengan menuliskan jawaban, jawaban benar dan lengkap hanya 9 peserta didik dari 40 peserta didik.Kemudian pada aspek mengecek kembali, hanya 5 dari 40 peserta didik yang melakukan pengecekan kembali atas pelaksanaan pemecahan masalah dan membuat kesimpulan dengan tepat dan benar.

Hasil wawancara peneliti dengan peserta didik mengenai tes yang telah dilakukan, diperoleh informasi sebagai berikut: (1) soal yang diberikan sulit dan peserta didik tidak memahami cara menyelesaikannya; (2) peserta didik hanya menyelesaikan soal tersebut susuai apa yang peserta didik ingat pada saat guru menjelaskan; (3) peserta didik bingung cara pengerjaan soal sehingga peserta didik hanya menyelesaikan soal tersebut menurut cara mereka sendiri.

Pada uraian diatas, terdapat masalah di kelas VII-2 SMPN 9 Pekanbaru.Permasalahan tersebut di antaranya pembelajaran hanya berlangsung satu arah.Peserta didik tidak terlibat aktif dalam pembelajaran, serta yang paling utama peserta didik tidak mampu menyelesaikan soal dengan langkah pemecahan masalah sehingga menyebabkan KPMM peserta didik rendah.Berdasarkan permasalahan yang telah dipaparkan, diperlukan suatu model pembelajaran yang inovatif dan menarik sehingga mampu membiasakan peserta didik terhadap persoalan-persoalan yang berkaitan dengan KPMM. Salah satu pembelajaran yang mampu meningkatkan KPMM peserta didik adalah model Problem Based Learning (PBL) dilihat berdasarkan kajian beberapa jurnal ataupun hasil penelitian yang relevan dengan model Problem Based Learning (PBL) dan kemampuan pemecahan masalah matematis.

\section{METODE}

Jenis penelitian yang dilakukan adalah Penelitian Tindakan Kelas (PTK). Penelitian ini terdiri dari dua siklus, masing-masing siklus terdiri dari tiga kali pertemuan dan satu kali ulangan harian. Pada siklus pertama dilakukan tindakan menggunakan dan mengacu pada penerapan model PBL, selanjutnya siklus kedua tindakan yang dilakukan adalah berdasarkan hasil refleksi dari siklus pertama. Menurut Arikunto (2017) secara garis besar penelitian tindakan kelas dilaksanakan melalui empat tahap meliputi: (1) perencanaan; (2) pelaksanaan; (3) pengamatan; dan (4) refleksi.

Populasi pada penelitian ini adalah seluruh peserta didik VII-2 SMPN 9 Pekanbaru. Subjek pada penelitian ini adalah peserta didik kelas VII-2 SMPN 9 Pekanbaru tahun pelajaran 2019/2020 sebanyak 40 orang yang terdiri dari 23 peserta didik laki-laki dan 17 peserta didik perempuan dengan tingkat kemampuan heterogen dan dilaksanakan pada semester ganjil tahun pelajaran2019/2020.

Instrumen pengumpul data yang digunakan adalah lembar pengamatan aktivitas guru dan aktivitas peserta didik serta tes KPMM. Data KPMM diperoleh berdasarkan nilai tes evaluasi akhir. Penilaian tes evaluasi akhir peneliti kembangkan berdasarkan indikator untuk mengukur KPMM yang dikemukakan oleh (modifikasi Ali Hamzah, 2014). Data yang diperoleh melalui pengamatan dan tes KPMM peserta didik kemudian dianalisis menggunakan teknik analisis deskriptif naratif dan analisis statistic deskriptif. Data yang diperoleh dari lembar pengamatan merupakan data kualitatif dan dianalisis dengan teknik analisis deskriptif naratif yang bertujuan menggambarkan data tentang aktivitas guru dan peserta didik selama proses pembelajaran dan memaparkannya dalam 
bentuk narasi. Data yang diperoleh dari tes KPMM peserta didik dianalisis dengan teknik analisis statistik deskriptif.

Pada penelitian ini, KPMM peserta didik dikatakan mengalami peningkatan apabila terjadi peningkatan rerata skor KPMM peserta didik dari skor dasar ke skor tes KPMM siklus I dan siklus II. Keadaan tersebut terjadi apabila terdapat peningkatan KPMM peserta didik. Kriteria keberhasilan tindakan pada penelitian ini adalah sebagai berikut:

1) Terjadinya Perbaikan Proses Pembelajaran. Terjadinya perbaikan proses pembelajaran jika aktivitas guru dan peserta didik mengalami peningkatan. Selain itu, juga terjadi kesesuaian antara langkah-langkah penerapan PBL yang direncanakan dengan pelaksanaan tindakan pada proses pembelajaran yang dapat dilihat dari lembar pengamatan setiap pertemuan. Perbaikan proses pembelajaran dilakukanberdasarkan hasil refleksi terhadap proses pembelajaran yangdiperoleh melaluilembarpengamatan aktivitas guru dan peserta didik.

2) Peningkatan Kemampuan Pemecahan Masalah Matematis Peserta Didik. Pada penelitian ini, KPMM peserta didik dikatakan mengalami peningkatan jika lebih dari $50 \%$ peserta didik mencapai minimal kategori baik dan terjadi peningkatan skor KPMM peserta didik dari skor awal ke skor tes KPMM siklus I dan skor KPMM siklus II.

3) Peningkatan Kemampuan Pemecahan Masalah Matematis Secara Klasikal. Peningkatan KPMM secara klasikal dapat dilihat dari nilai rerata KPMM peserta didik pada tes awal, siklusI, dan siklus II. KPMM secara klasikal meningkat jika nilai rerata KPMM peserta didik pada siklus I lebih tinggi dibandingkan nilai rerata pada tes awal KPMM. KPMM secara klasikal juga meningkat jika nilai rerata KPMM peserta didik pada siklus II lebih tinggi dibandingkan nilai rerata pada siklus I.

\section{HASIL DAN PEMBAHASAN}

Pada setiap pertemuan, proses pembelajaran sudah menjadi lebih baik dari pembelajaran sebelumnya. Hal ini terlihat diantaranya, peserta didik sudah tampak baik dalam berdoa, peserta didik selalu menginformasikan kehadiran sesuai dengan yang sebenarnya, guru selalu menyampaikan tujuan pembelajaran, peserta didik sudah aktif dalam menjawab apersepsi yang diberikan guru, guru berusaha mengarahkan peserta didik yang berbeda untuk menjawab apersepsi pada setiap pertemuan, peserta didik sudah aktif dalam member respon ketika guru menyampaikan motivasi mengenai pembelajaran yang dilakukan, peserta didik sudah dapat memahami langkah-langkah pembelajaran yang dilakukan, peserta didik selalu tertib dalam pembentukan kelompok, peserta didik sudah dapat menuliskan jawaban LKPD sesuai dengan kolomnya, peserta didik dapat menjelaskan solusi dengan baik, terlihat dari suara peserta didik yang terdengar lantang dan sudah tidak terbata-bata, peserta didik mulai paham dan dapat menuliskan kesimpulan pembelajaran. Selain itu, peserta didik dapat menuliskan kesimpulan materi pembelajaran, peserta didik yang memberi komentar selalu bertambah, serta peserta didik selalu diberikan tes individu dan PR oleh guru.

Pada analisis hasil tes KPMMI (Ulangan Harian I) rerata skor peserta didik untuk setiap aspek KPMM dapat dilihat pada Tabel 2 berikut. 
Tabel 2. Rerata Skor Peserta Didik Kelas VII-2SMPN 9 Pekanbaru pada Setiap Aspek KPMM Indikator Keterampilan Siklus 1

\begin{tabular}{crrrr}
\hline \multirow{2}{*}{ Nomor Soal } & \multicolumn{4}{c}{ Hasil Analisis } \\
\cline { 2 - 5 } & MM & MP & MR & MK \\
\hline 1 & 86,66 & 82,50 & 86,66 & 45,83 \\
2 & 90,00 & 86,66 & 92,50 & 56,66 \\
3 & 92,50 & 73,33 & 90,83 & 50,00 \\
4 & 70,33 & 35,83 & 80,00 & 35,33 \\
5 & 90,83 & 47,50 & 59,16 & 16,66 \\
6 & 82,50 & 60,00 & 85,83 & 51,66 \\
\hline
\end{tabular}

Tabel 2 menunjukkan informasi tentangskorKPMMpeserta didik padasetiap aspeknya.Terlihat padaTabel 2 peserta didik sudah mulai menyelesaikan persoalan pemecahan masalah berdasarkan indikator KPMM meskipun masih ada beberapa peserta didik yang melewatkan langkah pemecahan masalah terutama pada aspek perencanaan penyelesaian dan pemeriksaan kembali proses dan hasil. Terlihat dari tabel rerata skor pada soal nomor lima untuk aspek merencanakan penyelesaian banyak peserta didik yang tidak dapat memahami persoalan sehingga tidak menuliskan perencanaan penyelesaian hingga melaksanakan perencanaan. Berikut penjelasan mengenai peningkatan skor KPMM peserta didik pada siklus I berdasarkan aspek-aspek kemampuan pemecahan masalah matematis pada indikator keterampilan.

\section{Kemampuan Memahami Masalah}

Kemampuan peserta didik dalam memahami masalah matematis mengalami peningkatan dibandingkan sebelum dilaksanakan tindakan kelas. Pada saat diberikan tes kemampuan awal, banyak peserta didik yang langsung menuliskan rumus dan mengerjakan permasalahan matematika.Beberapa diantaranya tidak memahami masalah yang sedang dikerjakan sehingga hasil penyelesaian soal belum tepat. Hal ini sejalan dengan penelitian yang dilakukan oleh Azizah,dkk (2019) yang menyatakan bahwa pada tahap ini beberapa peserta didik masih melakukan kesalahan dalam memahami masalah dan juga beberapa peserta didik juga terbiasa dengan soal rutin. Pada tahap pemahaman masalah, peserta didik diminta untuk mengidentifikasi unsur-unsur yang diketahui, ditanyakan, dan informasi lain yang diperlukan. Pada soal keempat hingga soal keenam, sebagian besar peserta didik hampir mencapai skor maksimum untuk aspek pemahaman masalah. Hal ini dikarenakan peserta didik dapat menuliskan apa yang diketahui dan ditanyakan dalam soal secara tepat. Dari keenam soal keterampilan tersebut, pada soal kelima hampir seluruh peserta didik menuliskan diketahui dan ditanya dalam soal, akan tetapi masih belum lengkap sehingga banyak yang tidak mencapai skor maksimum.

\section{Kemampuan Merencanakan Penyelesaian}

Pada tahap ini, peserta didik diharapkan dapat menyusun model matematika dan merancang penyelesaian masalah untuk memudahkan dalam menyelesaikan permasalahan.Pada kondisi awal sebelum diberikan tindakan, masih banyak peserta didik yang belum mampu merancang rencana penyelesaian soal matematika yang diberikan. Hal tersebut dikarenakan peserta didik belum dapat memahami masalah sehingga tidak mengerti langkah apa yang harus dikerjakan. Hal ini sejalan dengan penelitian yang dilakukan oleh Suraji,dkk (2019) yang menyatakan bahwakesalahan dalam memilih dan menencanakan penyelesaian untuk menyelesaikan masalah matematika yaitu sebesar $7,14 \%$ maka tergolong dalam kriteria sangat rendah. Berdasarkan hasil tes siklus I, sebagian besar peserta didik sudah mulai menuliskan perencanaan penyelesaian dengan tepat dibandingkan dengan hasil tes kemampuan 
awal.Namun, masih terdapat beberapa peserta didik yang tidak menuliskan perencanaan penyelesaian dengan tepat, hal ini dikarenakan peserta didik salah dalam mengidentifikasi masalah sehingga peserta didik kesulitan dalam merencanakan penyelesaian soal yang diberikan.

\section{Kemampuan Melaksanakan Rencana}

Pada tahap ini peserta didik menyelesaikan masalah matematika sesuai dengan langkah yang telah direncanakan. Jika peserta didik mengalami kesalahan dalam merencanakan penyelesaian, maka hasil penyelesaian juga akan salah. Pada kondisi awal sebelum dilakukan tindakan, sebagian besar peserta didik dapat menyelesaikan persoalan, namun hanya setengah ataupun sebagian besar jawaban saja yang benar.Hal tersebut dikarenakan peserta didik melewatkan langkah memahami masalah serta belum dapat merencanakan penyelesaian masalah dengan benar.Hal ini sejalan dengan penelitian yang dilakukan oleh Nuraini,dkk (2019) yang menyatakan bahwadalam tahap melaksanakan rencana sangat tergantung pada pengalaman peserta didik untuk lebih kreatif dalam menyusun rencana penyelesaian suatu masalah, pada tahap melaksanakan rencana terlihat beberapa peserta didik melakukan kesalahan dalam penyelesaian karena rumus yang digunakan juga tidak sesuai dengan yang diharapkan soal.Sebagian besar peserta didik salah dalam melaksanakan perencanaan penyelesaian pada soal kedua, keempat dan kelima.Banyak peserta didik yang salah dalam menentukan konsep mana yang tepat untuk menyelesaikan soal matematika yang diberikan.Hal ini disebabkan oleh peserta didik kurang tepat dalam merumuskan masalah.

\section{Kemampuan Mengecek Kembali}

Pada kondisi awal sebelum tindakan, dari dua soal yang diberikan hanya tiga peserta didik yang memperoleh skor maksimal pada aspek pemeriksaan kembali proses dan hasil. Peserta didik belum terbiasa mengecek atau memeriksa kembali yang telah diperoleh. Berdasarkan hasil tindakan siklus I, masih terdapat beberapa peserta didik yang tidak menuliskan kesimpulan di akhir penyelesaian soal. Peserta didik yang memeriksa atau melihat kembali langkah penyelesaian akan menghitung lagi soal yang telah dikerjakan dengan lebih teliti. Sedangkan peserta didik yang lain merasa hasil pekerjaannya sudah benar sehingga tidak perlu dilakukan pemeriksaan lagi. Hal ini sejalan dengan penelitian yang dilakukan oleh Nuraini,dkk (2019) yang menyatakan bahwa pada tahap mengecek kembali yang terdiri dari kegiatan mengguakan pemeriksaan secara khusus terhadap setiap informasi dan langkah penyelesaian dan menggunakan pemeriksaan secara umum untuk mengetahui masalah secara umum dan pengembangannya, namun pada tahap ini beberapa peserta didik tidak melakukan tahap mengecek kembali. Jadi untuk memperbaiki kekurangan ini, peneliti memberikan pengertian tentang pentingnya melihat kembali langkah penyelesaian dan meminta peserta didik melakukan pemeriksaan hasil pekerjaan baik kesesuaian langkah penyelesaian dengan masalah yang diminta serta perhitungan yang telah dikerjakan.

Berdasarkan analisis hasil tes KPMM II (Ulangan Harian II) diperoleh rerata skor peserta didik untuk setiap aspek KPMM yang dapat dilihat pada Tabel 3 berikut. 
Tabel 3. Rerata Skor Peserta didik Kelas VII-2 SMP Negeri 9 Pekanbaru pada Setiap Aspek KPMM Indikator Keterampilan Siklus II

\begin{tabular}{crrrr}
\hline \multirow{2}{*}{ Nomor Soal } & \multicolumn{4}{c}{ Hasil Analisis } \\
\cline { 2 - 5 } & MM & MP & MR & MK \\
\hline 1 & 97,50 & 83,33 & 98,33 & 70,00 \\
2 & 96,66 & 84,16 & 94,16 & 59,16 \\
4 & 99,16 & 83,33 & 99,16 & 76,66 \\
5 & 96,16 & 78,33 & 90,83 & 66,66 \\
6 & 91,66 & 68,33 & 82,50 & 49,16 \\
& 99,66 & 85,00 & 99,16 & 72,50 \\
\hline
\end{tabular}

Tabel 3 di atas, menunjukkan informasi bahwa skor pada setiap aspek semakin meningkat dari siklus I. Dari enam soal keterampilan yang diberikan, secara umum peserta didik banyak melakukan kesalahan pada soal kelima, yaitu merencanakan penyelesaian masalah masih kurang tepat, sehingga terjadi kesalahan dalam melaksanakan penyelesaian. Secara keseluruhan, KPMM peserta didik semakin meningkat dibandingkan pada siklus I ataupun tes kemampuan awal sebelum pemberian tindakan. Meskipun masih terdapat beberapa peserta didik yang melewatkan langkah memeriksa kembali proses dan hasil, namun skor yang diperoleh tetap meningkat dibandingkan siklus sebelumnya. Analisis kualifikasi KPMM peserta didik sebelum dan sesudah penerapan model PBL pada materi pokok Himpunan dapat dilihat padaTabel 4 berikut.

Tabel 4. Peningkatan Frekuensi pada Setiap Kualifikasi KPMM Peserta Didik

\begin{tabular}{ccccc}
\hline Interval Skor & $\begin{array}{c}\text { Jumlah Peserta } \\
\text { Didik pada Tes } \\
\text { Kemampuan Awal }\end{array}$ & $\begin{array}{c}\text { Jumlah } \\
\text { Peserta } \\
\text { Didik pada } \\
\text { Siklus I }\end{array}$ & $\begin{array}{c}\text { Jumlah Peserta } \\
\text { Didik pada Siklus } \\
\text { II }\end{array}$ & $\begin{array}{c}\text { Kualifikasi } \\
\text { KPMM }\end{array}$ \\
\hline $85,00-100$ & 3 & 13 & 21 & Sangat Baik \\
$70,00-84,99$ & 5 & 9 & 14 & Baik \\
$55,00-69,99$ & 3 & 13 & 5 & Cukup \\
$40,00-54,99$ & 9 & 5 & - & Kurang \\
$0-39,99$ & 20 & - & - & Sangat Kurang \\
\hline
\end{tabular}

Tabel 4 di atas,menunjukkan informasi tentang penerapan model PBL, KPMM peserta didik pada setiap kualifikasi memperoleh peningkatan. Pada tes kemampuan awal, sebagian besar kualifikasi KPMM peserta didik tergolong sangat kurang. Namun pada siklus I mengalami peningkatan kualifikasi menjadi cukup serta memperoleh kualifikasi baik dan sangat baik pada siklus II. Pada siklus I dan II, tidak ada lagi peserta didik yang memiliki kualifikasi sangat kurang. Berikut ini analisis peningkatan KPMM secara klasikal sebelum dan sesudah penerapan model PBL pada materi pokok Bentuk Aljabar.

Tabel 5. Peningkatan Peningkatan KPMM Secara Klasikal Peserta Didik Kelas VII-2 SMPN 9 Pekanbaru pada Materi Pokok Bentuk Aljabar

\begin{tabular}{cccc}
\hline Rerata Setiap Aspek & Tes Awal & Siklus I & Siklus II \\
\hline Rerata aspek MM & 67,08 & 76,52 & 94,99 \\
Rerata aspek MP & 51,24 & 54,58 & 69,71 \\
Rerata aspek MR & 27,91 & 76,10 & 82,77 \\
Rerata aspek MK & 11,24 & 39,71 & 54,85 \\
Rerata skor KPMM & 39,82 & 70,15 & 85,62 \\
\hline
\end{tabular}


Tabel 5 di atas, menunjukkan informasi tentang peserta didik pada indikator keterampilan mengalami peningkatan dari tes kemampuan awal ke siklus I dan siklus II.Hal ini tidak terlepas dari peran model PBL dalam meningkatkan kemampuan pemecahan masalah matematis peserta didik. Kekurangan-kekurangan yang terjadi pada siklus I peneliti perbaiki pada siklus II. Hal ini terlihat dari peran model PBL dalam meningkatkan kemampuan pemecahan masalah matematis peserta didik.

Pembahasan ini dilakukan atas hasil pengamatan melalui lembar pengamatan aktivitas guru dan peserta didik dalam belajar matematika serta analisis hasil tes KPMM peserta didik melalui soal tes akhir siklus. Dari hasil wawancara peneliti dengan guru matematika pada observasi awal sebelum tindakan, diketahui bahwa kemampuan pemecahan masalah matematis peserta didik tergolong rendah karena peserta didik cenderung pasif dalam mengungkapkan pemikirannya. Selain itu, peserta didik hanya memperhatikan dan mendengarkan penjelasan guru serta mengandalkan catatan yang dibuat oleh guru matematika. Berdasarkan paparan tersebut, dapat disimpulkan bahwa kemampuan pemecahan masalah matematis peserta didik tergolong kurang baik. Peneliti ingin memperbaiki proses pembelajaran matematika dengan menerapkan model PBL pada pembelajaran matematika. Tujuannya untuk membantu meningkatkan KPMM peserta didik. Berdasarkan analisis data tentang aktivitas guru dan peserta didik, penerapan model pembelajaran sudah berjalan sesuai dengan perencanaan. Selama proses pembelajaran di kelas VII-2 SMPN 9 Pekanbaru berlangsung, terlihat peserta didik semakin aktif. Penerapan model ini telah memberikan kesempatan pada peserta didik untuk aktif dalam proses pembelajaran diantaranya menanggapi apersepsi dan motivasi, diskusi LKPD dalam kelompok, terlatih untuk menyelesaikan soal pemecahan masalah, dan berani mengajukan pertanyaan dan menyampaikan pendapat.

Kriteria keberhasilan tindakan dapat dikatakan bahwa tindakan yang peneliti lakukan telah berhasil karena adanya peningkatan KPMM dengan menerapkan model PBL di kelas peserta didik kelas VII-2 SMPN 9 Pekanbaru. Sejalan dengan pendapat yang disampaikan oleh Sanjaya (2012) bahwa PTK dikatakan berhasil jika masalah yang dikaji semakin mengerucut atau melaui tindakan setiap siklus masalah semakin terpecahkan dilihat dari aspek tes KPMM peserta didik dar siklus I ke siklus II semakin meningkat.

Terdapat beberapa kendala selama proses penelitian, hal ini tidak terlepas dari kekurangan peneliti dalam proses pembelajaran. Pada siklus I proses pembelajaran belum seluruhnya sesuai dengan perencanaan. Kekurangan-kekurangan tersebut diantaranya alokasi waktu yang tidak sesuai dengan perencanaan, peserta didik cenderung bekerja secara individu, peneliti tidak memberikan PR dan tes formatif pada pertemuan pertama, kurangnya pemahaman peserta didik terhadap langkah-langkah pengerjaan LKPD serta peserta didik kurang partisipatif dalam presentasi kelompok. Kekurangan- kekurangan tersebut menjadi bahan perbaikan bagi peneliti untuk melakukan tindakan pada siklus II. Proses pembelajaran pada siklus II mengalami perbaikan dari proses pembelajaran pada siklus I karena peserta didik sudah terbiasa mengikuti proses pembelajaran dengan menerapkan PBL.

Proses pembelajaran pada siklus II sudah sesuai dengan perencanaan. Kesalahan peserta didik yang dilakukan peserta didik berdasarkan analisis ketercapaian aspek KPMM pada hasil ulangan harian I dan II adalah peserta didik kurang tepat dalam merumuskan penyelesaian masalah sehingga peserta didik mengalami kesalahan dalam menyelesaikan masalah. Selain itu, peserta didik tidak melaksanakan semua langkah penyelesaian dalam pemecahan masalah. Ide perbaikan kesalahan peserta didik disarankan kepada guru dalam pelaksanaan pembelajaran selanjutnya. Pembelajaran sebaiknya dilakukan dengan menambah soal latihan berbentuk pemecahan masalah dalam proses pembelajaran. Berdasarkan data yang diperoleh pada siklusI dan siklus II, setelah diberikan tindakan secara keseluruhan KPMM peserta didik mengalami 
peningkatan. Rata-rata tes KPMM peserta didik pada siklus II meningkat menjadi 84,07dibanding dengan hasil tes pada siklus I hanya 70,27 dan pada tes awal KPMM hanya 39,82. Pada tindakan siklus I, peneliti telah mengenalkan kepada peserta didik mengenai pentingnya menyelesaikan suatu persoalan pemecahan masalah dengan menggunakan langkah-langkah pemecahan masalah. Namun, pada hasil tes siklus I masih terdapat beberapa peserta didik yang melewatkan langkah pemecahan masalah. Pada siklus II, peneliti memperbaiki kekurangan-kekurangan yang terjadi pada siklus I sehingga tidak ada lagi peserta didik yang melewatkan langkah pemecahan masalah.

PBL dalam penelitian ini meningkatkan KPMM peserta didik sebagaimana penelitian terdahulu yang telah dilakukan beberapa peneliti, di antaranya penelitian yang dilakukan oleh Mahera,dkk (2018) dan Gunantara,dkk (2014) yang menyatakan penerapan model PBL meningkatkan KPMM peserta didik yang diterapkan pada pembelajaran kurikulum 2013. Hal ini juga sejalan dengan penelitian Maimunah,dkk (2019) dimana PBL selain dapat meningkatkan KPMM juga dapat meningkatkan pemahaman matematika.

Berdasarkan analisis aktivitas guru dan peserta didik serta analisis hasil KPMM peserta didik dapat disimpulkan bahwa hipotesis tindakan yang diajukan dapat diterima kebenarannya. Dengan demikian, penerapan model PBL dapat meningkatkan KPMM peserta didik kelasVII-2 SMPN 9 Pekanbaru pada materi pokok Bentuk Aljabar tahun pelajaran 2019/2020.

\section{SIMPULAN}

Hasil penelitian yang telah peneliti lakukan, dapat disimpulkan bahwa penerapan model PBL meningkatkan kemampuan pemecahan masalah matematis peseta didik kelas VII-2 SMPN 9 Pekanbaru semester ganjil tahun pelajaran 2019/2020 pada materi pokok Bentuk Aljabar.

\section{UCAPAN TERIMA KASIH}

Ucapan terima kasih disampaikan kepada lembaga yang telah mendukung terlaksanya penelitian ini.Ucapan terima kasih ditujukan kepada Universitas Riau, Dinas Pendidikan dan Kebudayaan Provinsi Riau dan SMPN 9 Pekanbaru.

\section{DAFTAR PUSTAKA}

Arikunto. Suharsimi., Suhardjono., \& Supardi. (2017). Penelitian Tindakan Kelas. Bumi Aksara. Jakarta.

Azizah.,Maimunah., \& Yenita Roza.(2019). Kemampuan Pemecahan Masalah Matematis Siswa Pada Materi Peluang Berdasarkan Self-Regulated Learning (S-RL).Jurnal Review Pembelajaran Matematika. 4(1),23-31. http://jurnalftk.ac.id/index.php/jrpm

Gunantara.Gd., Md. Suarjana.,\& Pt. Nanci Riastini. (2014). Penerapan Model Pembelajaran Problem Based Learning Untuk Meningkatkan Kemmapuan Pemecahan Masalah Matematis Siswa Kelas V. Jurnal Mimbar PGSD Universitas Pendidikan Ganesha. 2(1). https:// ejournal.unidiksha.ac.id

Hamzah, A. (2014).Evaluasi Pembelajaran Matematika.Raja Grafindo Persada. Jakarta.

Hedriana. Heris., Rohaerti Euis Eti., \&Utari Sumarno. (2017). Hard Skills Dan Soft Skills Matematika Siswa.PT Refika Aditama. Bandung.

Mahera.A., Titi.S.,\& Armis. (2018). Penerapan Model Pembelajaran Berdasarkan Masalah Untuk Meningkatkan Kemampuan Pemecahan Masalah Matematis Siswa Kelas 『VII]-(B-2 ) MTS DARELL HIKMAH PEKANBARU.JOM FKIP VOLUME 5 EDISI 
http://jom.unri.ac.id/index.php/JOMFKIP/article/view/20131

Maimunah., Syarifah. N., \& Badrulaini. (2019). Peningkatan Kemampuan Matematis Siswa melalui penerapan Model Pembelajaran Berdasarkan Masalah Pada Materi Matriks.Edu Math Journal Pendidikan Matematika FKIP Jombang.Vol 8, No 1. https://ejournal.stkipjb.ac.id

Mawaddah.S., \& Anisah.H. (2015). Kemampuan Pemecahan Masalah Matematis Siswa Pada Pembelajaran Matematika dengan Menggunakan Model Pembelajaran Generatif (Generative Learning) di SMP. Jurnal Pendidikan Matematika 3(2):166-175. https://ppjp.ulm.ac.id

Nuraini., Maimunah., \& Yenita.R. (2019). Analisis Kemampuan Pemecahan Masalah Matematis Kelas VIII SMPN 1 Rambah Samo Pada Materi Bangun Ruang Sisi Datar.Jurnal Matematika dan Pendidikan Matematika Vol. 3, No. 1, Juni 2019. http://journal.iaimnumetrolampung.ac.id/index.php/numerical

Pemendiknas No 22 Tahun 2016 tentang Standar Proses Pendidikan Dasar dan Menengah

Sanjaya, W. (2011). Penelitian Tindakan Kelas.Kencana Prenada Media Group Jakarta.

Suraji., Maimunah., \& Saragih.S. (2019) Analisis Kemampuan Pemahaman Konsep Matematis dan Kemampuan Pemecahan Masalah Matematis Siswa SMP pada Materi Sistem Persamaan Linear Dua Variabel (SPLDV). Suska Journal of Mathematics Education.Vol 4, No. 1. https://scholar.google.co.id

Widodo. Suprih. ,\& Kartika Sari. (2017). Pembelajaran Pemecahan Masalah Matematis Siswa Sekolah Dasar Dengan Model Creative Problem Solving (CPS). Jurnal Prisma Universitas Surya Kancana. Vol 6, No 1. https://jurnal.unsur.ac.id 